OLEKSANDRA KACHMAR, Doctor of Philosophical Sciences, Associate Professor, The Department of Professional Methods and Primary Education Technologies Vasyl Stefanyk Precarpathian National University, Ukraine ORCID ID: 0000-0002-2002-4603 Ooleksandra75@ukr.net OKSANA KRYTSAK, senior lecture of the Department of English Language, Ivano-Frankivsk National Technical University of Oil and Gas, Ukraine ORCID iD 0000-0002-3305-2582 oksana.krytsak@gmail.com

\title{
LEARNING ENGLISH TROUGH MUSIK IN THE DIGITAL AGE
}

\author{
ОЛЕКСАНДРА КАЧМАР, доктор філософських \\ наук, професор, кафедра фахових методик і технологій \\ початкової освіти, ДВНЗ "Прикарпатський \\ національний університет імені Василя Стефаника" \\ ОКСАНА КРИЦАК, старший викладач кафедри \\ англійської мови, Івано-Франківський національний \\ технічний університет нафти і газу
}

\section{РОЛЬ МУЗИКИ ПРИ ВИВЧЕННІ АНГЛІЙСЬКОЇ МОВИ В СУЧАСНОМУ СУСПІЛЬСТВІ}

This article aims to highlight the impact of music in teaching English as a second language. It discusses different approaches and techniques which can assist English language students to improve their learning skills by using technology. Special attention is paid to audio-lingual method and in particular to the role of songs in learning English. Music offers special benefits for those learning a new language. Listening to songs and singing is a natural and enjoyable way to practice new sounds, words, and phrases. In fact, learning a song or musical instrument is analogous in many ways to learning a language. Modern technology helps to provide students with music lessons. During these lessons instead of focusing on one single task for the entire study session, it is possible to mix things up: do listening, learn new vocabulary, then study grammar, read and write a short story on the same topic. The variety will keep the students engaged and make studying more fun. The authors suggest different types of activity to make lessons more effective. The extensive

(c) O. Kachmar, O. Krytsak memorization, repetition and overlearning of patterns are the key to the method's success.

Key words: listening and speaking drills, new vocabulary, singing English songs, sentence structures, sounds, memory, lexical and grammatical skills, repeat, revise, communication competence.

Анотація. Автори статті ставлять за мету дослідити та висвітлити вплив музики у викладанні англійської мови. У статті розгянуто різні підходи та методики, використання котрих допоможе студентам опанувати англійську мову та покращити лексичні і граматичні навички. Особлива увага приділяється аудіолінгвістичному методу та важливій ролі пісень у вивченні англійської мови. Музика надає особливу перевагу тим, хто вивчає нову мову, сприяючи процесу запам'ятовування нових лексичних та граматичних конструкцій. Прослуховування пісень та співів - природний і приємний спосіб практикувати нові звуки, слова та фрази. Вивчення пісень, опанування гри на музичному інструменті багато в чому подібні до вивчення іноземної мови. Сучасні технології сприяють використанню му- зики на заняттях англійської мови. Під час таких занять замість того, щоб зосередитись на одному завданні, можна одночасно слухати англійську пісню, вивчити нову лексику, а також граматику, читати та писати коротку розповідь. Така різноманітність робить заняття цікавим та $\epsilon$ ефективним. Автори пропонують різні види діяльності, котрі сприятимуть запам'ятовуванню необхідного матеріалу, повторенню та розвитку комунікативної компетенції, що є запорукою успіху викладання.

Ключові слова: навички слухання та говоріння,нова лексика, прослуховування та спів англійських пісень,структура речення,звуки,лексичні та граматичні навички,повторювати,пригадувати,комунікативна компетенція.

Introduction. The methodology of teaching English has been developing recently. Among the popular methods are such as: grammar translation, direct method, audio-lingual, communicative language teaching and others. Each method is based on a particular vision of understanding the language or the teaching process and has a different focus or priority. 
Modern English teacher should know the various methods and choose the techniques with a focus on motivation helping learners to become independent, and inspire them to learn more. The best results are achieved when a teacher use specific techniques and materials in a particular set sequence.

1. Problem statment. According to the academic research, linguists have demonstrated that there is not one single best method for everyone in all contexts, and that no one teaching method is inherently superior to the others. Also, it is not always possible to apply the same methodology to all learners, who have different objectives, environments and learning needs (https://blog.tjtaylor.net/ teaching-methods/). An experienced professional language teacher faces the task to find the most suitable techniques and apply the most appropriate method for the learner's specific objectives, learning style and context.

Analysis of the recent research and publications. Language teaching methodology has been studied by many foreign and Ukrainian linguists for a long time. A more or less classical formulation suggests that methodology links theory and practice. Within methodology a distinction is often made between methods and approaches, in which methods are held to be fixed teaching systems with prescribed techniques and practices, and approaches are language teaching philosophies that can be interpreted and applied in a variety of different ways in the classroom. In this article a special attention is given to audio-lingual method. This method was widely used in the 1950s and 1960 s, and the emphasis was not on the understanding of words, but rather on the acquisition of structures and patterns in common everyday dialogue. These patterns are elicited, repeated and tested until the responses given by the student in the foreign language are automatic. The actual method rose from the work of structural linguists Charles C. Fries and Robert Lado. Basing their work on a combination of the study of the English language structure and basic concepts of behavioral psychology, especially in the work of B. F. Skinner, these linguists developed a method that focused on listening and speaking. Reading and writing were relegated to later stages of language study. O. Cherpack compared audiolingual and audio-visual methods of teaching English. A. Yuliana studied the effectiveness of audio-lingual method as an alternative method in improving the students' speaking. According to O. Cherpak audiolingual method is advised that students can be taught a language directly, without using native language to explain new words or grammar in the target language. However, unlike the direct method, the audio-lingual method didn't focus on teaching vocabulary. Rather, the teacher drilled students in the use of grammar. Applied to language instruction, and often within the context of the language lab, this means that the instructor would present the correct model of a sentence and the students would have to repeat it. But audio-lingual/visual approach did mark start of the technological age in language teaching and it did introduce important new elements.

Nowadays some methods and techniques are not necessary or popular but others are enhanced with technological progress. The audiolingual method is still in use today, though normally as a part of individual lessons rather than as the foundation of the course. These types of lessons can be popular as they are relatively simple, from the teacher's point of view, and the learner always knows what to expect. Some of the most famous supporters of this method were Giorgio Shenker, who promoted guided self learning with the Shenker method in Italy, and Robin Callan, who created the Callan method.

The audio-lingual method, based upon language structure, naturally treated the sounds of language as important building blocks for the creation of utterances, that is, meaningful strings of sounds. Some characteristics of this method are:

- Drills are used to teach structural patterns

- Set phrases are memorised with a focus on intonation

- Grammatical explanations are kept to a minimum

- Vocabulary is taught in context

- Audio-visual aids are used

- Focus is on pronunciation

- Correct responses are positively reinforced immediately (Cherpak, http://confesp.fl.kpi.ua/ru/node/ 1060).
- The aim and task of the research is to investigate and analyze the role of songs in teaching English using the characteristics of audio-lingual method. This method focuses on sentences and patterns. Listening and speaking drills are practiced only in English. The task is to analyze the effectiveness of learning English though songs.

Reseach results. More than a hundred years ago, French scientist Pierre Paul Broca (1824-1880) identified a part of the left frontal hemisphere of the brain as the area in which the syntax of the language is processed. A century later, using magnetoencephalography (MEG) imaging, researchers found that music syntax was processed in that same area, named Broca's area. Fascinatingly, researchers found that Broca's area responded in a similar way to dissonant music and ungrammatical sentences. This finding suggested a close relationship between the "pattern making" activity found in both music and language. This was the first of many discoveries made possible in the field of brain research using equipment available at the time. Music is a tool that can be used to trigger neural activity in the brain. Actually, music is so powerful in the language classroom activity that it enhances a wide range of social and academic skills, activating memory, facilitating language development and fostering positive attitude to learning. Music offers special benefits for students who are learning a new language. Listening to songs and singing is a natural and enjoyable way to practice new sounds, words, and phrases. In fact, learning a song or musical instrument is analogous in many ways to learning a language. We are required to produce and employ a repertoire of specific sounds, learn new patterns and rules, and master the "syntax" of songs and compositions. As musicians become more proficient, they (like language learners) make closer approximations of the target sounds until they reach a level of ease and enjoyment, or "fluency" (Murphey T. Music \& Song. URL: https://www.academia.edu/).

Music accompanies us almost everywhere. Listening to music we eat, relax, go in for sports, work or travel, so learning English through songs is extremely relevant in today's society. Some forms of music, such as pop 
songs, work especially well for teaching English language learners. It's been proven that songs help to memorize, so we take advantage of students' ability to commit information to memory by using songs in the classroom. This is a particularly useful technique, as it can get them having fun in the classroom. The students might not even notice that they're learning. For teenagers learning a foreign language through songs is a great opportunity to combine their musical preferences and mastering four aspects of the language, such as reading, writing, speaking and listening.

By listening to English songs in class, it is possible to optimize the process of learning new vocabulary. The new song should be presented in an interesting and exciting way. For example, print out the words or word combinations of the song, check if students know all the word, then ask the students to put the the words in the correct order while they are listening to the song. Usually some of the words are repeated several times in the song. Repeating these words, a student remembers them correctly, as well as the rhythm of the English language. When learning English (or any foreign language), we come across many unusual sounds that we do not use when speaking Ukrainian; as in English they are pronounced differently stronger or weaker sounds. Being non-native English speakers we sometimes struggle with certain word pronunciations because we do not have similar sounds in our native tongue. Likewise, two words may be spelled very similarly, yet be pronounced quite different (for instance, "tough" and "though"), or you may encounter combinations of letters where one of them is silent (for example, the K in "knife","know"; W "whole"). Singing English songs helps students to repeat and pronounce right sounds loudly and clearly. The teacher presents vocabulary in relatively few sentence structures that gives students the tools to express themselves using new words. Songs are a powerful source of vocabulary for everyday communication. However, teenagers should be advised that sometimes words of informal everyday communication are used in songs. It is important to understand that English words have different meanings in different situations and may be inappropriate in formal communication and writing. Some teenagers find it difficult to speak English because they are embarrassed or insecure, in this case singing helps to overcome the obstacles mentioned above. The singing teenager feels free and excited when it does not come to special vocal data. Singing this is somewhat of a challenge for a teenager so in order for the learning to be effective it is worth to do the following:

1. Find a song or video online, preferably with subtitles.

2. Read the words of the song aloud. Translate unfamiliar words.

3. Listen to the song and read the words at the same time. Do it several times encouraging the students to sing the song.

4. After they have learnt the words of the song, try to sing it, not looking at the printed words of the song.

Repetition is a key to successful learning English and writing exercises are a great way to practice. At the end of the lesson ask the students to write a short story using the words from the song they have heard. By making a habit of writing, you'll find your reading and comprehension skills improve over time.

When choosing a song for a class, it is important to take into account the level of English language skills of the students; lexical or grammatical subjects of the lesson according to the requirements of the discipline. Developing a task should start with simpler ones and gradually move to more complex and larger ones. The tasks should be interesting and accessible, as well as facilitate the development of different types of communication skills. However, the question is how to choose the right song to study. First of all, it should appeal to students. Best song for learning English should:

- be not too long (1-3 couplets)

- be not too fast (easy to sing)

- contain vocabulary of everyday communication (but not too many new words)

- be understandable (all words can be heard).

It is mentioned above that English sounds are quiet different from Ukrainian ones so it is very important to learn new vocabulary and pronounce the words properly. For training pronounciation:
1. Print out the words of a students' favorite song or popular one.

2. Underline the words you are going to learn.

3. Specify the number of syllables in each underlined word.

4. Listen to the song and make sure you have the word spelled correctly. One of the syllables is pronounced louder?

5. Sing the song together.

6. Ask to clap along with syllables pronounced louder.

For example, let's take the famous song, "Walking the Wire" (Imagine Dragons)

There are many words of everyday communication: walk away, cry, tears, fade, price, pay, look out, take, your hand, thunder, roar, promise...). Most of the words are monosyllabic or twosyllable, with emphasis on the first syllable. All stressed syllables are pronounced stronger. Some words or sentences are mentioned several times:

Do you feel the same when I'm away from you?

Do you know the line that I'd walk for you?

We could turn around, or we could give it up

But we'll take what comes, take what comes

$\mathrm{Oh}$, the storm is raging against us now

If you're afraid of falling, then don't look down

But we took the step, and we took the leap

And we'll take what comes, take what comes

The teacher can use this repetition to emphasize correctly any sound or articulation the students have shown problematic. Besides this repetition reinforces the listening aspect of language, allowing students immediately recognize the sentence they have just pronounced. The students will remember the song better if it is taught at several lessons and in couplets.

Singing also helps you learn how words fit together. Therefore, through the songs you can teach not only vocabulary but also grammar of English.

The song mentioned above can be used to study or revise tenses: Present Simple (It's the price we pay when it comes to love. Do you feel the same when I'm away from you?...), 
Present Continuous (the storm is raging against us now...), Past Simple (But we took the step, and we took the leap...), Future Simple (we'll cry, but those tears will fade...); Imperative Mood (Feel the wind in your hair. Feel the rush way up here).

Learning English through the songs promotes to form and develop not only lexical and grammatical skills that are the basis of communication competence, but also reading, writing and listening skills.

To form and develop reading skills:

1. Print out the words of the song.

2. Cut the printed text into pieces.

3. Ask students to make couplets in the correct order.

4. Listen to the song again and make sure everything is correct.

To form and develop writing skills:

1. Listen to the song in verse, then fully.

2. Ask students to write a small piece about something that appeared in their minds as they listened to the song.

3. Students can write what video they would make for this song, and then you can watch the official video.

Students need to learn how to highlight the basic idea and important information of the text, so it is important what thoughts and emotions they have while listening to a song. In this way songs can contribute to writing compositions.

To form and develop your listening skills:

1. Choose10 words from the song and add 5 more.

2. Write words in random order.

3. Give the list of words to the students so that they only notice the words they hear listening to the song.

4. Print out the words of the song but change 5-10 words in it. Students should correct mistakes by listening to a song.

For example, some tasks to do at the lesson when using the popular song Perfect (Ed Sheeran):

1. Print out the word of the song (look down!). Listen to the song and correct mistakes.

I found a love for me

Darling just dive (sleep) right in

And follow my lead

Well I found a girl beautiful and sweet

I never knew (saw) you were the someone waiting (dancing) for me

'Cause we were just kids when we fell in love

Not knowing what it was

I will not give ( miss) you up this time

But darling, just kiss me slow, your heart is all I own

And in your eyes you're holding mine (me)

Baby, I'm dancing in the dark ( shadow) with you between my arms

Barefoot on the grass (floor), listening to our favorite song

When you said you looked a mess, I whispered( cried) underneath my breath

But you heard it, darling, you look perfect (bright) tonight

Well I found a woman, stronger than anyone I know

She shares (watched) my dreams, I hope that someday I'll share her home

2. Mark the words or phrases (Pometun, 2004) that sounded in the song: carry, fighting, odds, storm, hold, my hair, walk away, night, favorite song, looking, thunder, higher, faith, listening, deserve.

I found a love, to carry more than just my secrets

To carry love, to carry children of our own

We are still kids, but we're so in love

Fighting against all odds

I know we'll be alright this time

Darling, just hold my hand

Be my girl, I'll be your man

I see my future in your eyes......

Conclusion and prospects for further research. The students learn more by doing and singing, and they love learning the lyrics of their favourite singers or bands. Songs work equally well to promote different aspects of language and digital technology help us to make lessons more interesting and effective. Learning English trough the songs certainly can bring musical appreciation and musical experiences into English classrooms, with all the benefits they provide: mprove students' motivation; reinforce grammatical structures; enhance pronunciation and vocabulary; help memorize patterns and make learning easier; build fluency. There are many ways you can bring music and songs into your English classroom. The simplest one is to use students' mobile phones. There are a few websites popular with ESL teachers to assist with using music in the classroom: https:// childrensmusic.org/; http:// larryferlazzo.edublogs.org/larryferlazzos-english-website; http:// w w w . e s l c a f e . c o m/i d e a / index.cgi?display:913437837-1091.txt (Taylor, 2015).

\section{REFERENCES}

Cherpak, O. Audio-lingual and audio-visual methods of teaching. Retrieved from http:// confesp.fl.kpi.ua/

Lems, K. New ideas for teaching English using songs and music. Retrieved from https:// www.linkedin.com/

Murphey, T. Music \& Song. Retrieved from https:// www.academia.edu/

Nickerson, R. S. (1994). Teaching of thinking and problem-solving. San Diego : CA: Academic press.

Pometun, O. I., Pyrozhenko L.V. (2004). Suchasnyi urok. Enteractyvni tehnologii. Kyiv: A.S.C.

Stern, N. N. (1983). Fundamental concepts of language teaching. Oxford : Oxford University Press.

Taylor, T. (2015). Language Training. Retrieved from http:// blog.tjtaylor.net/

Стаття надійшла 1.05.2020 p. 